\title{
Pattern of Collection Development in Academic Libraries in Andhra Pradesh: A Study
}

\author{
Prof.C.Sasikala, Dr.G.Nagaratnamani, V.Dhanraju \\ Dept.of Library\&Information Science, Andhra University, Visakhapatnam, India \\ Librarian, Knowledge Resource Center, GITAM University, Visakhapatnam, India \\ Asst.Professor, Dept.of Library\&Information Science, Andhra University, Visakhapatnam, India
}

\begin{abstract}
Academic libraries which are considered to be nerve centers of academic and research activities must help achieve the academic goals of their parent institutions and this is possible only through developing adequate library collection and/or providing seamless and wider access to relevant electronic resources. Chukwu (1998) maintains that the major indicator of a good library is the quality and quantity of its collections. It is necessary for university libraries to acquire current and relevant information resources necessary for sustaining the teaching, learning, and research activities that universities are known for. This paper chiefly investigates the trends in collection development activities in university and college libraries. Further the contemporary changes in scholarly publishing and advances in Information and Communication technologies are posing challenges to library professionals in developing and making them accessible to the end users. This article describes briefly the impact of electronic publishing on collection development in libraries. It also examines the status and management of electronic resources in academic libraries surveyed and enlists the challenges before library professionals in the changed context. It also explores the kind of collaborative initiatives taken up by these libraries and the perceptions of the library professionals on collaborative collection development
\end{abstract}

\section{Introduction:}

Collection development is one of the important and challenging library management activity. Collection development is a process of selecting, ordering and payment of information materials for the use of the users in the library (Olaojo and Akewukekere ,2006). Based on this, collection development helps to enhance the assemblage and provision of a variety of information materials to meet the desperate need of library users. Nnadozie (2006) described collection development as a planned, continuous and cost effective acquisition of quality and relevant materials to meet the needs of the users and objectives of the university libraries.

Collection development is concerned with the formulation of a systematic plan to build a library collection which will meet the needs of its users. It encompasses a number of activities related to the development of the library's collection including the determination and coordination of selection policy, assessment of current and potential user needs, collection use studies, collection evaluation, identification of collection needs, selection of materials, planning of resource sharing, collection maintenance and weeding (Gorman and Howes, 1989; Clayton and Gorman, 2001).

\section{Review of literature}

The review of literature reveals the findings of number of studies on various aspects of collection development. Forecasting the impact of electronic environment and the economic forces on collection development, Harole and Budd (1994) felt that together they create a new environment, where access to collective scholarly resources that no library could be ever afford, supersedes the historic quest for the great comprehensive collection. Ifidon (1997) maintains that library objectives and philosophy must be taken into consideration in collection development, emphasizing that the areas of interest and concerns of library users are paramount. Nwafor (1997) discovered that a low level of funding of university libraries had led to the deterioration in the quality of library collections. Akobo (1998) discovered that problems facing library collections in Nigeria include foreign exchange restrictions, economic recession, and the large population of students. Evans(2000) stressed the need to have a collection development policy in the context of hybrid collections to delineates the purpose and contents of a collection relevant to its users as a whole. Further a well written Collection Development Policy typically identifies subject areas in which it may be preferable to have one format over another (Lee and $\mathrm{Wu}, 2002$ ). Ononogbo (2003) discovered that 91 percent of the collection in the library being studied was derived from donations, gifts, and bequests. A collection development policy is therefore needed that delineates the purpose and contents of a collection relevant to its users as a whole (Evans, 2000; Futas, 1984) 
Tucker and Terrence (2004) observe that there are many challenges facing new librarians in the academic environment, including collection development. This article analyzes the topic of collection development and how it relates to new professionals in the field of librarianship. Attama (2005) identifies ways in which university libraries can build their collections, including legal deposits, exchange, direct purchase, donation, donations, and photocopies.

The study of Hsieh and Runner (2005) includes a survey targeting academic collections development and acquisition librarians and an analysis of academic collection development policies. Also, the study describes treatment of materials, library policies reasoning, impact of faculty and students on policy changes and other related factors. Manda and Panda (2005) have described different dimensions of collection development with specific reference to Engineering College Libraries. They have analyzed data on library collection received from 17 major Engineering College Libraries of West Bengal and enumerated the activities of seven major library consortiums of the world engaged in sharing resources among Engineering college libraries. The paper by Vignau, Barbara Susana Sanchez (2005) is based on both research about collection development policies and data compiled as a result of a survey of 16 centers of higher and technical education in Cuba. The results have indicated that although the directors of university libraries and managers of collection development were aware of the process of collection development, only few actually adopt and implement a policy for the same and carry out user studies. Wittenbach, Stefanie (2005) proposes the restructuring of collection development at the University of California Riverside University Libraries. The author describes the new system that has created more accountability for the materials budget. As a result of the new system, faculty members are more aware of the budgeted amount for monographic purchases in their own area and whom they can contact with concerns or purchasing requests. Ameen, Kanwal (2006) discusses all kinds of managerial and practical issues pertaining to collection development and acquisitions to collection management. However, there appears to be gaps in LIS literature regarding tracing the semantic developments of the subject. The paper attempts to explore the relationship between the use of varying collection-related terminologies and ever-emerging forms of scholarly publishing in libraries. It was found that the related emerging terminology has been expanding rapidly because of the direct impact of the never-ending developments, though with different pace in different countries. The varying use pattern reflects the expansion in the aims and ways of functioning of a modern library. Vignau, Barbara Susana Sanchez (2006) have discussed the Collection Development in a digital environment and have mainly focused on user-oriented concept of development in digital collections. They believe that developing digital collections is a logical consequence of inserting information technologies in organizations. They have rightly concluded that the usual route towards other models of libraries has allowed the development of the digital collections as a source of digital Libraries. Jones (2007) categorizes collections into four areas: materials to support students' learning and teaching, materials to support researchers, special collections, and "just in case" materials.

The literature of collection development is vast. General treatments of academic library collection development include Gessesse (2000), Nisonger (1999), Rowley and Black (1996), Seth, Ramesh, and Sahu (1997), Susana, Vignau, and Meneses (2005), Taylor (1999), and Wessels (1995). Explorations of particular countries and case studies of individual libraries include Andrada and Vergueiro (1996), Maharana, Choudhury, and Dutta (2004), and Sinha and Tucker (2005). Digital collections are of particular interest. Authors who discuss this topic include Arlitch and Johnson (2005), Cole and Shreeves (2004), Kiondo (2004), Leung (2005), Nikolaidou et al. (2005), and Ashoor (2005). Tools such as metadata systems and software are pertinent to collection development. Works on those topics include Bekaert, et al. (2002), Calanag, Tabata, and Suginoto (2004), and Mutula and Makondo (2003).

\section{Methodology}

This study is a survey of college and university libraries in Andhra Pradesh, India. The survey sought to determine the nature of the collection, procedures and policies followed to develop collections, nature and composition of e-resources, budget allocations for them, their selection, access, evaluation and withdrawal procedures and policies and the type of collaborative activities they are involved.

\section{Objectives of the Study:}

The following objectives have been pursued for the purpose of the study on collection development, in select college and university libraries of Andhra Pradesh

1. To cull up information regarding the collections in select college and university libraries located in Andhra Pradesh and also to examine the budget for printed documents as well as e-resources.

2. To examine and study the collection development policy of college and university libraries in the terms of printed and electronic documents

3. To critically study the selection criteria, acquisition process and to examine the weeding out or de-selection criteria of the documents. 
4. To reveal the present status of print, non-print, and e-resources in the libraries under study.

5. To examine and evaluate collection development policies of the college and university libraries

6.To find out details regarding the nature of allocation of funds for print and e-resources and the impact of economic factors on fund allocation

7.To survey the perceptions of library professionals on various aspects of collection development including collaborative activities

\section{Survey findings}

The following sections of this article describe the findings of the present survey under different headings.

1. Institutional profile.

The survey covers four state University Libraries, four Central University Libraries, one private owned University library and nine College libraries functioning under private management. Out of them highest percent (77.77\% ) of libraries are established between 1951 to 2000.

\section{Printed sources-collection development.}

\subsection{Acquisition methods}

For acquiring print collection, various methods were adopted by the libraries surveyed. The following table reveals details regarding this aspect

Table: 2. Acquisition Methods

\begin{tabular}{|c|l|c|}
\hline S No & Methods followed & $\begin{array}{c}\text { No. of libraries } \\
\%\end{array}$ \\
\hline a & Donation/gifts & $6(33.33)$ \\
\hline b & Membership & $8(44.44)$ \\
\hline c & Exchange of material & $3(16.66)$ \\
\hline d & Purchase & $18(100.00)$ \\
\hline e & Any other, please specify & $0(0.00 \%)$ \\
\hline
\end{tabular}

Among various methods of acquiring print collections, collection development through purchases stood in the first place with all the libraries (100\%) opted for it. The second highest percent (44\%) are acquiring the documents through membership in various professional associations and institutions. Collections were also added in 33 percent of the libraries in the form donations and gifts. Only 16 percent of them are receiving documents through exchange of publications with other institutions.

\subsection{Participant in selection process.}

Before placing orders for procurement of documents it is customary to select the materials that are relevant by the librarian and others as per the policy of the library. The data in the following table identifies the persons or bodies involved in selection process besides the librarian.

Table: 3. Participants in Selection process (more than one answer)

\begin{tabular}{|c|l|c|}
\hline S No & Participation & No. of Libraries $(\%)$ \\
\hline a & Librarian & $9(50.00)$ \\
\hline b & Acquisition section in charge & $6(33.33)$ \\
\hline c & Users & $11(61.11)$ \\
\hline d & Library Advisory Committee & $7(38.88)$ \\
\hline e & Any other, please specify & $0(0.00)$ \\
\hline
\end{tabular}

The analysis of data shows that the user in each library plays the key role in choosing the relevant titles $(61.11 \%)$. Almost in half of the libraries, librarian exercises his/her decision on selection process along with others. The library advisory committee is participating in selection process in nearly 39 percent of the libraries also. Acquisition librarian is also found to be participating in about 33 percent of the libraries surveyed.

\subsection{Tools used for selecting material}

While marking decisions on selection of various titles, different selection tools will be consulted by the librarian and his staff. Table 4 presents the particulars on the selection tools often referred by the librarian.

Table: 4. Tools used for selecting Materials

\begin{tabular}{|l|l|l|}
\hline S No & Tools used & No. of Libraries $(\%)$ \\
\hline
\end{tabular}




\begin{tabular}{|c|l|c|}
\hline a & Vendors list & $10(55.55 \%)$ \\
\hline b & Publisher's catalogue & $15(83.33 \%)$ \\
\hline c & Reviews & $6(33.33 \%)$ \\
\hline d & Bibliographies & $5(27.77 \%)$ \\
\hline e & Suggestions from users & $14(77.77 \%)$ \\
\hline f & Online search & $9(50.00 \%)$ \\
\hline g & Any other, please specify & $0(0.00)$ \\
\hline
\end{tabular}

(Syllabus of different courses)

It may be observed that the publishers Catalogues are the tools for selection on which highest percent of librarians (83.33\%) are depending for selection purpose. Next highest percent $(77 \%)$ are depending on the details given by the users. About 55 percent of the librarians are relying on vendors lists. Online search also has been done by 50 percent of the librarians for choosing and collecting the details of the titles selected. Dependency on reviews and bibliographies has been noticed among 33 percent and 27 percent librarians respectively.

\subsection{Hindrances to Acquisition}

The process of selection and acquisition of library materials is not a simple activity free problems and issues. Number of factors may be creating hurdles for smooth development of collections in libraries. The obstacles that are noticed by the libraries are explored and presented in the following table.

Table: 5. Hindrances to Acquisition

\begin{tabular}{|c|l|c|}
\hline S No & Obstacles & No. of Libraries $(\%)$ \\
\hline $\mathrm{a}$ & Lack of funds & $13(72.22 \%)$ \\
\hline $\mathrm{b}$ & Exchange rate & $4(22.22 \%)$ \\
\hline $\mathrm{c}$ & Economic recession & $2(11.11 \%)$ \\
\hline $\mathrm{d}$ & Hike in prices & $10(55.55 \%)$ \\
\hline $\mathrm{e}$ & Any other, please specify & $0(0.00)$ \\
\hline
\end{tabular}

Unable to acquire materials in time (NU)

Lack of funds for acquiring new items was stated as the main obstacle by highest percent of the librarians $(72 \%)$. About 55 percent felt that hike in prices of books and a journal is a big hurdle for them in their procurement.

\subsection{Use of specific print reference sources to assist in developing collections}

Number of standard selection tools are available to assist the librarians in selecting standards titles in different subjects. The presented also ascertained details about various printed reference books without which the libraries may not be able to complete the collection development activity.

Table 6: Printed Selection Tools

\begin{tabular}{|c|l|c|}
\hline S No & \multicolumn{1}{|c|}{ Used reference sources } & No. of Libraries $(\%)$ \\
\hline $\mathbf{1}$ & Books in Print & $\mathbf{8}(\mathbf{4 4 . 4 4 )}$ \\
\hline $\mathbf{2}$ & Indian National Bibliography & $\mathbf{5}(\mathbf{2 7 . 7 7})$ \\
\hline $\mathbf{3}$ & Ulrich International Periodical Directories & $\mathbf{4}(\mathbf{2 2 . 2 2})$ \\
\hline
\end{tabular}

It may be noticed that the three print reference sources on which librarians are depending are Books in print and Indian National Bibliography for books (44\% and $27 \%$ respectively) and Ulrich International Periodical Directory (22\%) for periodicals selection. However, it is also observed that less than 44 percent of them are consulting them for developing print collection.

\subsection{Use of essential free collection development related websites.}

For developing print collections the librarians also can consult various online websites of publishers, book stores and distributors. The following table reveals the most frequently visited websites by the librarians surveyed for this purpose.

\section{Table 8: Three Essential free Accessible Websites visited}

\begin{tabular}{|c|l|c|}
\hline S No & Response & No. of Libraries $(\%)$ \\
\hline a & Amazon.com & $7(38.88 \%)$ \\
\hline b & Google books.com & $8(44.44 \%)$ \\
\hline c & Global Books in Print & $5(27.77 \%)$ \\
\hline
\end{tabular}

Among different commercial free accessible websites of publishers, book stores, distributors and search engines Amazon.com occupied the first place with 44 percent of them using that website for the purpose of collection development. Google books.com occupied the second place in the list with nearly 39 percent of the 
librarians citing this source. About 22 percent are visiting Global Books in Print website for collecting details about the title to be procured.

\subsection{Library Webpage or Website to support Collection Development}

In order to support collection development related activities, libraries may maintain separate library home pages or websites. The present study have also collected detailed regarding this aspect

Table 9: Maintenance of Separate Library Webpage/Website to support CD

\begin{tabular}{|c|l|c|}
\hline S No & Response & No. of Libraries $(\%)$ \\
\hline a & Yes & $3(16.66 \%)$ \\
\hline b & No & $15(83.33 \%$ \\
\hline c & Total & $18(100.00 \%)$ \\
\hline
\end{tabular}

It is observed that only three libraries (16\%) are able to maintain a separate library webpage for collection development purpose. They have also indicated their URL for verification purpose.

\subsection{Approximate size of Monographic collection}

The present study has gathered the details about the size of monographic collection the libraries have.

Table: 13.. Approximate size of the monograph collection

\begin{tabular}{|c|l|c|}
\hline S No & Size of the monograph collection & No. of Libraries(\%) \\
\hline a & Less than 50,000 volumes & $2(11.11 \%)$ \\
\hline b & $50,000-99,999$ volumes & $2(11.11 \%)$ \\
\hline c & $1,00,0000-1,50,000$ volumes & $6(33.33 \%)$ \\
\hline d & More than 1,50,000 volumes & $8(44.44 \%)$ \\
\hline
\end{tabular}

The above table shows that highest percent of libraries have more than 1, 50,000 volume of ranging between $1,00,000$ to $1,50,000$. Only about 11 percent found to be having less than 50,000 monographs in their collection.

\subsection{Rationale behind the collection development}

Various reasons help the librarians to decide what kind of collection he/she has to develop for meeting the information needs of users. The opinions of the librarians on the factors influencing their decisions on collection development activity are presented in the following table.

Table: 13. Opinion on Library collection development

\begin{tabular}{|c|l|c|}
\hline S No & \multicolumn{1}{|c|}{ Opinion } & $\begin{array}{c}\text { No. of } \\
\text { Libraries }(\%)\end{array}$ \\
\hline a & $\begin{array}{l}\text { Based on unique requirements of academic community to support } \\
\text { current academic programmes }\end{array}$ & $2(11.11 \%)$ \\
\hline b & To support long-term research need of the users & $2(11.11 \%)$ \\
\hline c & As per budget allocations for current fiscal year & $4(22.22 \%)$ \\
\hline d & All the above & $10(55.55 \%)$ \\
\hline e & Any other, please describe & $0(0.00)$ \\
\hline
\end{tabular}

The responses of the librarians reveal different reasons that are influencing on collection development Highest percent of them $(55.55 \%)$ all the three reasons i.e. requirements of academics, researchers, and the budget allocation for a fiscal to gather will influence their decisions on collection development.

\subsection{Impediments to collection developments \& management in the organisation concerned.}

Earlier responses under heading 2.4 are related to the hindrances noticed by librarians for acquiring materials in general. Under this heading, the responses indicate the impediments noticed in individual organization for developing and managing library collections.

Table: 14. Impediments to implementing collection development and management

(More than one answer)

\begin{tabular}{|c|l|c|}
\hline S No & \multicolumn{1}{|c|}{ Impediments to collection development } & $\begin{array}{c}\text { No. of } \\
\text { Libraries(\%) }\end{array}$ \\
\hline a & Lack of expertise & $0(0.00)$ \\
\hline b & Lack of time for planning & $3(16.66 \%)$ \\
\hline c & Lack of funding & $11(61.11 \%)$ \\
\hline d & Lack of administrative support within the library & $3(16.66 \%)$ \\
\hline e & Lack of administrative support elsewhere in the institution & $0(0.00)$ \\
\hline f & No known impediments & $3(16.66 \%)$ \\
\hline
\end{tabular}


g $\quad$ Others (please describe) $0(0.00)$

The analysis of responses reveals interesting facts. Majority (61\%) pointed out lack of funding is main impediment to the development of collection in their libraries. About 16 percent as the impediment felt that due to lack of time for planning to the collection development activity. Another 16 percent stated that lack of administrative supportive with in the library is influencing their collection development programme. Three libraries $(16 \%)$, on the other hand state that they have not experienced any impediments to collection development activities in their libraries.

\subsection{Approximate amount spent on monographic acquisitions in current year}

During the current fiscal year, the libraries surveyed might have spent different amounts on procuring monographs. The details on approximate amounts spent in the year 2012 have been presented in the following table.

Table: 15. Approximate amount of monograph acquisition budget (Current) fiscal year

\begin{tabular}{|c|l|c|}
\hline S No & Amount spent on book acquisition & No. of Libraries(\%) \\
\hline a & Less than 25,000 & $2(11.11 \%)$ \\
\hline b & $25,000-49,999$ & $2(11.11 \%)$ \\
\hline c & $50,000-99,999$ & $3(16.66 \%)$ \\
\hline d & $1,00,000-3,00,000$ & $5(27.77 \%)$ \\
\hline f & Over $3,00,000$ & $6(33.33 \%)$ \\
\hline
\end{tabular}

It may be observed from the above table that about 22 percent of the libraries were able to spend over 3, 00,000 on book acquisitions in the year 2012. Nearly 28 percent spent between Rs. 1,00,000 to 3,00,000 for this purpose. About 11 percent of the libraries spent less than 25,000 rupees in the year 2012 on acquiring books.

\subsection{Materials on which the library spent increasing percentage of the library budget}

Usually the library budget is expected to increase in order to meet the increasing demands of users on new courses introduced. The following table shows on which type of collection, the increased percentage of budget has been spent by the libraries.

Table: 17. Increasing percentage of library budget last five years

\begin{tabular}{|c|l|c|}
\hline S No & Types of material & No. of Libraries(\%) \\
\hline a & Serials & $5(27.77 \%)$ \\
\hline b & Books & $7(38.88 \%)$ \\
\hline c & E-resources & $6(33.335)$ \\
\hline
\end{tabular}

It is noticed that highest percent of them (39\%) have spent the increased percentage of the budget on purchasing books followed by those libraries (33\%) that have spent increased portion of the budget on eresources. Some of the libraries spent the increase percentage of budget on subscribing to new journal titles or renewal of old serials.

\subsection{Status of Library budget for materials in keeping pace with inflation and price increase}

Due to the inflation and hike in prices of print materials, the libraries are facing problems with the inadequate and unscientific allocation of budgets for collection development. In this connection, the present study has tried to assess the status of the library material budget allocation to check whether it is kept pace with the inflation and hike in prices.

Table: 18. Influence of inflation and price increase on collection development

\begin{tabular}{|c|c|c|}
\hline S No & Response & No. of Libraries $(\%)$ \\
\hline $\mathrm{a}$ & Yes & $8(44.44 \%)$ \\
\hline $\mathrm{b}$ & No & $10(55.55 \%)$ \\
\hline $\mathrm{c}$ & Total & $18(100.00 \%)$ \\
\hline
\end{tabular}

The responses from librarians reveal that in majority of the libraries $(55 \%)$, the library material budget has not been increased in par with the inflation and price increase in the market. However, about 44 percent of the libraries have got the advantage of increase in library materials budgets along with inflation and increase in prices.

\subsection{Opinion of librarians on adequacy of current budget allocation}

Budget allocation in libraries varies depending on various factors. Adequacy of allocated funds to meet the expected needs of the users is an important factor in providing effective collections for use. The opinions of librarians on the adequacy of current budget for developing collection are analysed in the following table 
Table: 19.Opinion on adequacy of budget allocation for print as well as e-resources.

\begin{tabular}{|c|c|c|}
\hline S No & Response & No. of Libraries $(\%)$ \\
\hline a & Yes & $7(38.88 \%)$ \\
\hline b & No & $11(61.11 \%)$ \\
\hline c & Total & $18(100.00 \%$ \\
\hline
\end{tabular}

Majority of librarians (61\%) opined that the budget allocated for procuring all types of collection in the library. However, about 39 percent felt that whatever budget that is allocated for the current year as adequate to procure or access print as well as e-sources.

\subsection{Opinion on the need to have separate budget allocation for different types of documents}

Budget allocated for collection development may be a lump sum amount or it may be item wise budget. The present survey also attempted to know the opinion of the librarians on the type of budget they think best for their library for developing collections.

Table: 21.Need to have separate budget allocation for different types of documents

\begin{tabular}{|c|c|c|}
\hline S No & Response & No. of Libraries (\%) \\
\hline $\mathrm{a}$ & Yes & $18(100.00 \%)$ \\
\hline $\mathrm{b}$ & No & $0(0.00 \%)$ \\
\hline $\mathrm{c}$ & Total & $18(100.00 \%)$ \\
\hline
\end{tabular}

It is observed that, all the librarians responded to the survey (100\%) have felt the need to have separate budget allocation for different types of information sources.

\subsection{Opinion on review of budget allocation every year}

Since the dynamics of collection development in libraries changing because of the dynamic information environment there is a dire need to review the budget allocation periodically to make it more effective and need oriented. The responses presented in the following table exhibit the opinion of librarians on this issue.

Table 22. Opinion on review of budget allocation every year

\begin{tabular}{|c|c|c|}
\hline S No & Response & No. of Libraries $(\%)$ \\
\hline $\mathrm{a}$ & Yes & $18(100.00 \%)$ \\
\hline $\mathrm{b}$ & No & $0(0.00 \%)$ \\
\hline & Total & $18(100.00 \%)$ \\
\hline
\end{tabular}

As expected all the librarians unanimously felt that there is a need to review the previous year budget allocation every year to make it more suitable to current requirements.

\subsection{Budget related problems encountered in developing library collection}

Collection development is a set of process aimed at developing useful and cost effective collections. While performing this task the librarian must have faced different budget problem and issues. The following table presents a list of problems encountered by the librarian during the process of collection development.

Table 23 Budget related problems encountered

\begin{tabular}{|c|l|c|}
\hline S No & \multicolumn{1}{|c|}{ Budget related problems } & No. of Libraries(\%) \\
\hline a & budget restraint & $11(61.11 \%)$ \\
\hline b & Less books budget & $10(55.55 \%)$ \\
\hline c & Fluctuating budgets & $10955.55 \%)$ \\
\hline d & Inflation rates & $4(22.22 \%)$ \\
\hline e & No separate budget for e-resources & $14(77.78 \%)$ \\
\hline f & Any other, please specify & $0(0.00 \%)$ \\
\hline
\end{tabular}

The analysis of responses indicate various budget related problems encountered by the librarian during the process of collection development. Majority of them (77\%) faced the problem of lack of separate budget for eresources for developing balanced collection. Second highest percent $(61 \%)$ identified budget restraints as the main threat to proper collection development. An equal percent of librarians (55\% each) stated that inadequate books budget and the fluctuating budget created problems in fulfilling their task of planning and developing required collections for different user departments. Only 20 percent of librarians found to be bothered about the impact of increasing inflation rates on developing collections.

3 Collection Development -e-resources 


\subsection{Type of e-resources available.}

In addition to finding details about print resources, the present study has also focused on e-resource collection development. In order to know what type of e-resources accessible through the libraries the related data has been gathered and presented in the following table.

Table 24. Types of e-resources accessible

\begin{tabular}{|c|l|c|}
\hline S No & \multicolumn{1}{|c|}{ Types of E-resources } & No. of Libraries (\%) \\
\hline a & CD-Rom collections & $18(100.00 \%)$ \\
\hline b & E-Journals & $18(100.00 \%)$ \\
\hline c & E-Books & $6(33.33 \%)$ \\
\hline d & Online databases & $4(22.22 \%)$ \\
\hline e & In-house Databases & $18(100.00 \%)$ \\
\hline f & Any other, please specify & $0(0.00 \%)$ \\
\hline
\end{tabular}

E learning material $12(66.64)$

It is found that all the librarians surveyed have CD-ROM collections, access to e-journals and in house databases (100\%). About 44 percent libraries are providing access to online databases where as access to ebooks is provided by only about 33 percent of the libraries. Among others, nearly 67 percent of the libraries are found to providing access to e-learning materials to the academic community.

\subsection{Means of providing access to e-resources}

There are different ways of providing access to e-resources. Each library may adopt more than one way of providing access to choose the options they are adopting to provide access to e-sources to their library users.

Table 24: Means of providing access to e-resources (more than one answer)

\begin{tabular}{|c|l|c|}
\hline S No & \multicolumn{1}{|c|}{ Means of providing access to e-resources } & Number of Libraries (\%) \\
\hline a & UGC-INFLIBNET & $144.44 \%)$ \\
\hline b & AICTE-INDEST & $10(55.55 \%)$ \\
\hline c & Institutional website & $13(72.22 \%)$ \\
\hline d & Library home page/website & $2(11.11 \%)$ \\
\hline e & Intranet & $5(27.77 \%)$ \\
\hline f & Web OPAC & $4(22.22 \%)$ \\
\hline g & Campus Network & $5(27.77 \%)$ \\
\hline h & Any other, please specify. & --- \\
\hline
\end{tabular}

Among various means of providing access, majority of the libraries are providing acess to e-resources through their institutional website $(72 \%)$. The second highest percent $(55 \%)$ are able to facilitate access to eresources through AICTE-INDEST Consortia. The users about 44 percent libraries are accessing e-journals and databases through UGC-INFLINET Consortia. Through Intranet and campus network (WAN) also access to inhouse databases and CD-ROM sources has been provided by nearly 28 percent of the libraries. Access to inhouse databases through Web OPAC is made possible by 22 percent of the libraries.

\subsection{Criteria applied for making decisions on e-collections/subscriptions/purchases}

As in the case printed sources the decisions on e-collection development depends on different factors. The following table reveals the list of factors that aided in decision making on collections.

Table 25: Factors influencing the decisions e-collection

\begin{tabular}{|c|l|c|}
\hline S No & \multicolumn{1}{|c|}{ Types of E-resources } & No. of Libraries(\%) \\
\hline $\mathrm{a}$ & User request & $11(61.11 \%)$ \\
\hline $\mathrm{b}$ & Librarian choice & $7(38.88 \%)$ \\
\hline $\mathrm{c}$ & Research projects & $8(44.44 \%)$ \\
\hline $\mathrm{d}$ & Course curriculum & $14(77.78 \%)$ \\
\hline $\mathrm{e}$ & E-resource offers via online & $6(33.33 \%)$ \\
& 1.E-mail & $4(22.22 \%)$ \\
\hline $\mathrm{f}$ & 2.List serves & $5(27.77 \%)$ \\
\hline $\mathrm{g}$ & Regular mail & $0(0.00 \%)$ \\
\hline
\end{tabular}

Number of factors that aid in selecting and subscribing resources are listed in the table above. Highest percent of the librarians (nearly 79\%) are making the choice of required e-resources based on the curriculum of the courses offered by the institution. Another 61 percent are making decisions on e-resources as per requests from users. Based on the research projects, about 44 percent are taking decision on e-resources. Some of the librarians are motivated by online e-resource offers in the form of e-mails (33\%) and list serves (22\%) in selecting the e- 
resources for their users. In the case of 39 percent of libraries, decisions on the choice of e-resources are made by the librarian alone.

\subsection{Processes involved in purchasing or canceling e-resources}

For developing e-collections, providing access to them, archiving, evaluating and withdrawing or canceling them-all these activities can be performed with or without following standard process already laid down. Details about the process followed by libraries in e-resource purchase or cancel are shown in the following table

Table 27: Processes involved on purchasing or canceling e-resources

\begin{tabular}{|c|l|c|}
\hline S No & \multicolumn{1}{|c|}{ Process } & No. of Libraries (\%) \\
\hline a & No particular processes & $6(33.33 \%)$ \\
\hline b & Informal processes & $738.38 \%)$ \\
\hline c & Definite process & $5(27.77 \%)$ \\
\hline D & Total & $18(100.00 \%)$ \\
\hline
\end{tabular}

The responses of librarians reveals that majority of the libraries are following informal process for both purchasing or canceling the e-resources. No particular process has been adhered by 33 percent for this purpose. Only 27 percent of the librarians are found to be depending on definite processes for purchase or cancel of eresources.

\subsection{Existence of Collection Development Policy}

For systematic and effective development of library collections, a library always needs policy document reflecting the objectives, nature, scope and purpose of the collection to be developed and managed. The guide lines in the form of policy document assist the librarian in developing value added collection. In order to find out whether libraries surveyed are guided by any policy document on developing e-collections, details are collected, analysed and presented in the following table.

Table 28: Collection development policy-adopted by the library

\begin{tabular}{|c|l|c|}
\hline S No & \multicolumn{1}{|c|}{ Types of collection development } & No. of Libraries(\%) \\
\hline a & Specific policy & $0(0.00 \%)$ \\
\hline b & Part of general collection development policy & $12(66.66 \%)$ \\
\hline c & Do not have collection development policy & $8(44.44 \%)$ \\
\hline d & Format dependent policies & $0(0.00 \%)$ \\
\hline e & Any other, please specify & $0(0.00 \%)$ \\
\hline
\end{tabular}

The analysis responses indicates that none of the libraries have specific policy on developing e-resource collection. The guidelines for developing e-resources are part of the general collection development policy in the case of 66 percent of the libraries. About 44 percent found to be not at all having any collection development policy.

\section{6 .Decisions regarding E-resources}

The present survey has also attempted to find out the persons responsible for making decisions on the selection of e-resources. The responses of librarians were analysed and presented in the following table.

Table: 29. Decision making on E-resources

\begin{tabular}{|c|l|c|}
\hline S No & \multicolumn{1}{|c|}{ Decision making authority } & No. of Libraries(\%) \\
\hline a & Librarian alone & $3(16 . .66 \%)$ \\
\hline b & Committee of librarians & $0(0.00 \%)$ \\
\hline c & Electronic Resource Committee & $2(11.11 \%)$ \\
\hline d & Teaching faculty alone & $2(11.11 \%)$ \\
\hline e & College management & $4(22.22 \%)$ \\
\hline f & Any other, please specify -all the above & $7(38.88 \%)$ \\
\hline
\end{tabular}

In majority of the libraries $(38.88 \%)$ it is observed that the librarian along with college management, teaching faculty and committee are taking decisions on developing e-resources in their libraries. College management is responsible for all the decisions related to e-resources procurement in 22 percent of the libraries. In about 16 percent of the libraries, the librarian is involved in deciding the type of e-resources to be made accessible to their users.

3.7Mmethods of procuring e-resources and making them accessible 
E-resources can be made available to the users through different means. The responses analysed show different ways adopted by librarians to ensure access to e-resources.

Table: 30. Means/methods of acquiring e-resources

\begin{tabular}{|c|l|c|}
\hline S No & \multicolumn{1}{|c|}{ Channels } & No. of Libraries $(\%)$ \\
\hline a & Vendors/Publishers & $12(66.66)$ \\
\hline b & Distributors & $4(22.22)$ \\
\hline c & Gift/Donation & $0(0.00 \%)$ \\
\hline d & Exchange & $0(0.00 \%)$ \\
\hline e & Membership & $5(27.77)$ \\
\hline f & Free downloads from WWW/Internet & $8(44.44)$ \\
\hline G & Any other, please specify & $0(0.00 \%)$ \\
\hline
\end{tabular}

It is evident from the responses that majority of the libraries are getting access to e-resources through publishers and vendors of e-resources by subscribing to them (66.66\%). By downloading freely available econtent from WWW, about 44 percent of the librarians are providing access to them. By taking membership in a group, some of the libraries (nearly 28\%) are able to provide access to e-resources

\subsection{Use of specific set of criteria to evaluate the web resources}

While judging the quality and utility of e-resources, just like in the case print resources a set of evaluation criteria has to be applied. The following table indicates whether or not the libraries surveyed are applying any evaluative criteria for this purpose

Table: 31. Use of criteria to evaluate electronic resources

\begin{tabular}{|c|c|c|}
\hline S No & Response & No. of Libraries $(\%)$ \\
\hline a & Yes & $10(55.55)$ \\
\hline b & No & $8(44.44)$ \\
\hline c & Total & $18(100.00)$ \\
\hline
\end{tabular}

The responses revealed that 55 percent of the libraries are applying a list of check list points to evaluate the e-resources to which they provide access. However, 44 percent of the libraries are not using any criteria for evaluation of e-resources.

\subsection{Criteria applied for evaluation of e-resources}

It is observed that more than half of the libraries are using a set of evaluation criteria to evaluate e-resources. The following table highlights the type of criteria applied by the librarians for evaluation purpose.

Table: 32. Criteria used for electronic resource evaluation

\begin{tabular}{|c|l|c|}
\hline S No & \multicolumn{1}{|c|}{ Channels } & No. of Libraries $(\%)$ \\
\hline a & Quality(based on reviews, user needs etc) & $12(80.00 \%)$ \\
\hline b & Subject relevance & $15(100.00 \%)$ \\
\hline c & Currency, authority and completeness & $10(66.66 \%)$ \\
\hline d & Language & $11(73.33 \%)$ \\
\hline f & Uniqueness of the content & $10(66.66 \%)$ \\
\hline f & Relevance of materials for curriculum & $11(73.73 \%)$ \\
\hline h & Relevance of materials for faculty and research & $12(80.00 \%)$ \\
\hline i & Cost effectiveness & $7(46.66 \%)$ \\
\hline j & Trial before use & $13(86.66 \%)$ \\
\hline k & Network compatibility & $10(66.66 \%)$ \\
\hline l & Hardware and software compatibility & $8(53.33 \%)$ \\
\hline m & Strength of search engines/access & $6(40.00 \%)$ \\
\hline Remote accessibility & $11(73.33 \%)$ \\
\hline
\end{tabular}

Among 13 criteria listed in the questionnaire, highest percent (100\%) of libraries have checked for subject relevance to evaluate the collection. Verifying the content and coverage of the e-resources through trails before purchasing them has been noticed among 86 percent of the librarians. About 80 percent gave importance to quality of the resource based on reviews available and needs of their users. 73 percent of the librarians verified the relevance of material for faculty and research, language of content and remote accessibility as part of evaluation process. Factors like currency, authority and completeness, uniqueness of the content and network compatibility have also been considered by 66 percent to evaluate the e-resources they want to make accessible to their users. About 46 percent of the libraries even asked for the type of access given by the online vendors to the back files to make a decisions on subscribing to online databases or e-journals.

\subsection{Criteria followed to cancel the e-resources}


The present survey has also assessed the criteria for used by librarians to cancel or withdrawal of eresources

Table: 33. Criteria based on e-resources are cancelled or discontinued

\begin{tabular}{|c|l|c|}
\hline S No & \multicolumn{1}{|c|}{ Criteria followed } & No. of Libraries(\%) \\
\hline $\mathrm{a}$ & Usage statistics & $12(80.00 \%)$ \\
\hline $\mathrm{b}$ & Budget & $13(86.00 \%)$ \\
\hline $\mathrm{c}$ & Duplication & $13(86.00 \%)$ \\
\hline $\mathrm{d}$ & Dissatisfaction with a resource & $11(73.33 \%)$ \\
\hline $\mathrm{e}$ & Any other, Please specify & $0(0.00 \%)$ \\
\hline
\end{tabular}

The analysis of responses clearly states that while discontinuing or rejecting the e-resources, majority of the librarians $(86 \%)$ are making decisions based on the budget allocation for e-resources on one hand and the issue of duplication of items. Based on usage statistics (80\%) and the dissatisfaction felt(73\%) with the eresources made accessible also librarians are found to be making decisions on renewal or cancellations of subscriptions.

\subsection{Perceptions on the role of consortia in e-collection developed}

Consortia is a kind of cooperative and collaborative type of providing access or procuring the e-resources through a coordinating agency. Perceptions of librarians on consortia based e-collection development and the use of consortia are presented in the following table.

Table: 34. Perceptions of librarian on the role consortia in e-collection development

\begin{tabular}{|c|l|c|}
\hline S No & \multicolumn{1}{|c|}{ Awareness } & No. of Libraries(\%) \\
\hline a & Only able to purchase through the consortia because of the discounts that are available & $14(77.77 \%)$ \\
\hline b & Request consortia at research we are interested in & $5(27.77 \%)$ \\
\hline c & Use consortia to save on time & $8(44.44 \%)$ \\
\hline d & Use consortia to save on item they would buy any way & 3 \\
\hline e & Consortia are also a way for librarians to learn about what electronic resources are available & $8(44.44 \%)$ \\
\hline f & Do you think due to consortia model the role of selector is diminishing & $9(50.00 \%)$ \\
\hline $\mathrm{g}$ & $\begin{array}{l}\text { Virtual purchase of information sources limits the autonomy and change the role of the local } \\
\text { librarian }\end{array}$ & $9(50.00 \%)$ \\
\hline
\end{tabular}

Highest percent of the librarians agreed that they are able to purchase e-resources through the consortia because of the discounts available with the packages (nearly 78\%). Half of them $(50 \%)$ felt that the role of librarian in selection is diminishing due to the consortia model. An equal percent of them opined that the virtual purchase of information sources limits the autonomy of the librarian and changes the role of the local librarian $(50 \%)$. About 44 percent accepted that consortia help them to save on time in purchase activity and enable them to learn about the other available electronic sources.

\subsection{Perceptions of Librarians on e-resources collection development}

Perceptions of librarians on different policy issues related to e-resources collection development have been ascertained and analysed in table 35

Table: 35. Opinion on e-resource collection development

\begin{tabular}{|c|c|c|c|}
\hline S No & Opinion & Yes & No \\
\hline $\mathrm{a}$ & $\begin{array}{l}\text { There is a need to for long range planning and a structural committee process for } \\
\text { e-resource collection development }\end{array}$ & $\begin{array}{c}12 \\
(66.66 \%)\end{array}$ & $\begin{array}{c}6 \\
(33.33)\end{array}$ \\
\hline $\mathrm{b}$ & There is a need for a check list of criteria for evaluation & $\begin{array}{c}10 \\
(55.55 \%)\end{array}$ & $\begin{array}{c}8 \\
(44.44 \%)\end{array}$ \\
\hline $\mathrm{c}$ & $\begin{array}{l}\text { The librarian is not able to devote adequate time on the criteria of such processes } \\
\text { and selection criteria }\end{array}$ & $\begin{array}{c}6 \\
(33.33)\end{array}$ & $\begin{array}{c}12 \\
(66.66 \%)\end{array}$ \\
\hline $\mathrm{d}$ & $\begin{array}{l}\text { There is problem deciding quantitatively the level of use to consider for evaluating } \\
\text { the usefulness of the library resources }\end{array}$ & $\begin{array}{c}8 \\
(44.44 \%)\end{array}$ & $\begin{array}{c}12 \\
(66.66 \%)\end{array}$ \\
\hline $\mathrm{e}$ & $\begin{array}{l}\text { Digital collection } \quad \text { development } \\
\text { collaboration beyond libraries include } \\
\text { the process }\end{array}$ & $\begin{array}{c}13 \\
(72.22 \%)\end{array}$ & $\begin{array}{c}5 \\
(27.77 \%)\end{array}$ \\
\hline f & $\begin{array}{l}\text { Collection development policy is influenced by changing access to information } \\
\text { 1. Changes in the model used by providers (ex: not offering institutional access) } \\
\text { 2. The changing and nature of the required items (ex: expensive industry databases } \\
\text { and reports ) }\end{array}$ & $\begin{array}{c}11 \\
(61.11 \%) \\
10 \\
(55.55 \%)\end{array}$ & $\begin{array}{c}7 \\
(38.88 \%) \\
8 \\
(44.44 \%)\end{array}$ \\
\hline $\mathrm{g}$ & $\begin{array}{l}\text { Exclusive awareness and knowledge is required to ensure access to electronic } \\
\text { resources on the part of librarian }\end{array}$ & $\begin{array}{c}16 \\
(88.99 \%)\end{array}$ & $\begin{array}{c}2 \\
(11.1 \%)\end{array}$ \\
\hline $\mathrm{h}$ & Library user needs guidance and training on the access and use of e-resources & $\begin{array}{c}14 \\
(77.77 \%)\end{array}$ & $\begin{array}{c}4 \\
(22.22 \%)\end{array}$ \\
\hline
\end{tabular}


Among different statements, majority of the librarians (nearly 78\%) felt that exclusive awareness and knowledge is required to ensure access to electronic resources on the part of librarian. 78 percent of them also stressed that need for providing guidance and training to the library user on the access and use of e-resources. Librarians also opined that digital collection development requires more collaboration beyond libraries including IT developments and legal developments in process (72\%). Further nearly 67 percent emphasized the need for long range planning and structural committee process for e-resource development. According to them the collection development policy is influenced by changes in the model used by providers $(61 \%)$ and the changing nature of required items $(55 \%)$.

Some of the statements about e- collection development have not been fully accepted by majority of the libraries. About 67 percent of them differed with the statement that the librarian is not able to devote adequate time on the criteria of selection process. An equal percent have also not agreed with the assumption that there is problem for deciding quantitatively the level of use of e-resources for evaluation purposes. About 44 percent felt that there is no need for a check list for evaluation.

\subsection{Cost effective strategies in case of budget - pressure on library}

It is a known fact that some of the libraries are facing savior budgets cuts. As a result it become challenging for librarians to develop balanced and value added information sources. In order to find out the strategies followed by the librarians to handle such situation, various options are given. The responses are analysed and tabulated in the following table

Table: 36. Budget pressures- cost effective strategies adopted

\begin{tabular}{|c|l|c|}
\hline S No & \multicolumn{1}{|c|}{ Opinion } & Percent \\
\hline $\mathrm{a}$ & Move from print and electronic subscriptions to e-only & $8(44.44 \%)$ \\
\hline $\mathrm{b}$ & $\begin{array}{l}\text { Cancel databases to eliminate duplicate content and retain databases with the most } \\
\text { unique full text }\end{array}$ & $7(38.88 \%)$ \\
\hline $\mathrm{c}$ & Break up e-packages and renew only the most used e-journals in a package & $9(50.00 \%)$ \\
\hline $\mathrm{d}$ & $\begin{array}{l}\text { Try to negotiate multiyear a package agreements(low prices, lower annual price } \\
\text { increase caps }\end{array}$ & $\begin{array}{c}11 \\
(61.11 \%)\end{array}$ \\
\hline e & Seek alternative open access content & $8(44.44 \%)$ \\
\hline f & Consolidate subscription vendors for better pricing & 12 \\
\hline g & Consolidate software/access and management services to achieve better pricing & $3(66.66 \%)$ \\
\hline h & Any other, please specify & $0(0.00 \%)$ \\
\hline
\end{tabular}

\section{Participation in consortia to face financial crisis (NU)}

More than one option has been chosen by the librarians. Highest percent of them $(72 \%)$ wanted to be come member of a consortia as a solution to the budget constraints. The second highest percent of them have thought about consolidating subscription vendors for better pricing (nearly 67\%). Another 61 percent of them wish to negotiate multiyear a package agreements (slow prices, lower annual price increase caps). Half of them (50\%) are thinking of e-packages and renew only the most used e-journals in a package. Another solution thought about by 44 percent librarians it is move from print and electronic subscriptions to e-only subscriptions. An equal percent of the librarians are thinking of trying for alternative open access content. Few of them (16\%) only thought about consolidating software, access and management services to achieve better pricing.

\subsection{Opinion on the usefulness of library standards and guide lines in collection development process}

Standards and guidelines are developed to bring uniformity and consistency in the procedures followed, services offered and physical facilities developed by libraries for sake of library users.

Table: 37.Impact of standards on Collection Development

\begin{tabular}{|c|c|c|}
\hline S No & Response & No. of Libraries $(\%)$ \\
\hline $\mathrm{a}$ & Yes & $18(100.00 \%)$ \\
\hline $\mathrm{b}$ & No & $0(0.00 \%)$ \\
\hline $\mathrm{c}$ & Total & $(100.00 \%)$ \\
\hline
\end{tabular}

The responses from the librarians clearly indicate the importance of standards and guide lines. All of them unanimously accepted that they are helpful in developing effective collections.

\subsection{Usefulness of standards in collection development}

In continuation to the previous question, the librarians were also asked to indicate how the standards are helpful to them in developing library collections. The following table presents their responses. 
Table: 38.Opinions on usefulness of standards in collection development

\begin{tabular}{|c|l|c|}
\hline S No & \multicolumn{1}{|c|}{ Opinion } & No. of Libraries(\%) \\
\hline a & provides a direction and helps in planning CD & $15(83.33 \%)$ \\
\hline b & gives a frame work with scope & $11(61.11 \%)$ \\
\hline c & helps in proper dispersion of resources & $16(88.88 \%)$ \\
\hline d & helps in justifying the funds & $15(83.33 \%)$ \\
\hline e & $\begin{array}{l}\text { helps in maintain uniformity in composition and size of the collection in similar type of } \\
\text { libraries }\end{array}$ & $14(77.77 \%)$ \\
\hline f & any other, please specify & $0(0.00 \%)$ \\
\hline
\end{tabular}

The responses from the librarians showed that standards for collection development are helping them in different ways in developing library collections. Highest percent of them (nearly 89\%) stated that the standards helped them in two ways by providing direction and help in planning collection development and in justifying the funds allocated both in terms of sanction and also expenditure. More than 78 percent have also felt that standards help in maintaining uniformity in composition and size of the collection in similar type of libraries.

\subsection{Suggestions}

Suggestions offered by the librarians on different aspects of collection development are grouped and presented in the following table

Table: 39. Suggestions offered by the librarians

\begin{tabular}{|c|l|c|}
\hline S No & \multicolumn{1}{|c|}{ Suggestions offered by the professionals } & No. of Libraries (\%) \\
\hline a & Separate collection development policy for e-resources & $16(88.88 \%)$ \\
\hline b & Separate budget for different types of e-resources & $14(77.77 \%)$ \\
\hline c & Fixed budget for libraries form institutional budget & $11(61.11 \%)$ \\
\hline d & Library staff should be trained in e-resources & $12(66.66 \%)$ \\
\hline e & Staff should be more involved in CD programme & $6(33.33 \%)$ \\
\hline f & Faculty should have more freedom to purchase & $5(27.77 \%)$ \\
\hline g & To encourage the use of e-sources proper access facilities should be made available. & $10(55.55 \%)$ \\
\hline h & $\begin{array}{l}\text { To generate monetary resources for e-collection development, access to e-resources may be } \\
\text { charged/priced }\end{array}$ & $6(33.33 \%)$ \\
\hline
\end{tabular}

Among various suggestions offered by librarians, majority (nearly $89 \%$ ) stressed the need to have a separate policy for developing e-collections. Librarians opined that category wise budget allocation should be there for collection for development in libraries $(77 \%)$. While 66 percent pointed out the need to train the library in managing e-resources, another 61 percent insisted for provision of fixed budget.

\section{References:}

[1]. Ameen, Kanwal (2006) "From Acquisitions to Collection Management: Mere Semantics or An Expanded Framework for Libraries?" Collection Building, 25(2), 55-60.

[2]. Andrada, Diva and Vergueiro Waldomiro. Collection Development in Academic Libraries: A Brazilian Library's Experience.New Library World. 97 (4); 1996, Jul. 15-24. <http://www.emeraldinsight.com/10.1108/03074809610120171>

[3]. Arlitch, Kenning and Jonsson, Jeff. Aggregating Distributed Digital Collection in the Mountain West: Digital Library with the ContentDM Multi-Site Server. Library Hi Tech. $23 \quad$ (2); $\quad 2005$, Jun.; 220-232. <http://www.emeraldinsight.com/10.1108/07378830510605179>

[4]. Ashoor, Mohammad-Salch. Information Literacy: A Case Study of the KFUPM Library.The Electronic Library. 23 (4); 2005, Aug.; 398-409. <http://www.emeraldinsight.com/10.1108/02640470510611463>

[5]. Bekaert, Jeroen, et al. Metadata Based Access to Multimedia Architectural and Historical Archive Collection: A Review.Aslib Proceedings. 54 (6); 2002, Dec., 362-371. <http://www.emeraldinsight.com/10.1108/00012530210452564>

[6]. Calanag, Maria Luisa, Tabata, Koichi, and Suginoto, Shigeo. Linking Preservation Metadata and Collection Management Policies.Collection Building. 23 (2); 2004, Jun.; 56-63. <http://www.emeraldinsight.com/10.1108/01604950410514730>

[7]. Chukwu, O.C. (1988). The Role of the library in the accreditation of academic programme in Nigeria polytechnics: Need to improve standards though better funding. A paper presented at a Seminar on Standards of Library Services in Nigeria held at Yaba College of Technology,19th-21st December.

[8]. Clayton, Peter and G.E Gorman. 2001. Managing information resources in libraries: collection management in theory and practice. London: Library Association.

[9]. Cole, Timothy W. and Shreeves, Sarah L.. Search and Discovery across Collections: The IMLS Digital Collection and Content Project.Library Hi Tech. 22 (3); 2004, Sep.; 307-322. <http://www.emeraldinsight.com/10.1108/07378830410560107>

[10]. Evans, G. Edward. 2000. Developing library and information center collection. Englewood: Libraries Unlimited

[11]. Gessesse, Kebede. Collection Development and Management in the Twenty First Century with Special Reference to Academic Libraries.Library Management. 21 (7); 2000, Oct.; 365-372. 〈http://www.emeraldinsight.com/10.1108/01435120010372551>

[12]. Gorman, G.E and B.R. Howes. 1989.. Collection development for libraries 4th ed. London: Bowker - Saur.

[13]. Hsieh, C., Runner, R. (2005), "Textbooks, Leisure Reading, and the Academic Library", Library Collections, Acquisition and Technical Services, 29(2), 192-04.

[14]. ignau, Barbara Susana Sanchez (2006), "Collection Development in an Digital Environment: An Imperative for Information Organizations in the Twenty-First Century", Collection Building, 25(4), 139-144.

[15]. Kiondo, Elizabeth. Around the World To: The University of Dares Salaam Library: Collection Development in the Electronic Information Environment.Library Hi Tech News. $21 \quad$ (6); 2004, Jul.; 19-24. <http://www.emeraldinsight.com/10.1108/07419050410554861> 
[16]. Lee, Leslie A. and Wu, Michelle M. (2002). Do librarians dream of electronic serials? A beginner'sguide to format selection. The Bottom Line: Managing Finances. Vol. 15 (3), pp 102-109.

[17]. Leung, Shirley W. International Conference of Developing Digital Institutional Repositories: Experiences and Challenges. Library Hi Tech News. 22 (2); 2005, Feb.; 14-15. <http://www.emeraldinsight.com/10.1108/07419050510593335>

[18]. Maharana, Bulu, Choudhury, BK, and Dutta, Sxamashree. Collection Development of Electronic Information Resources in the R \& D Libraries of Kolkata City: A Survey.Library Herald. 42 (3); 2004, September; 235-245.

[19]. Mandal, M and Panda, K. C. (2005) "Collection Development in the Internet Age and the Need for Consortium in the Engineering College Libraries in West Bengal: A Study", SRELs Journal of Information. Management, 42(2), 155-172.

[20]. Mutula, Stephen M. and Makondo, Francina S. IT Skills Needs for Collection Development at the University Botswana Library.Library Hi Tech. 21 (1); 2003, Mar., 94-101. 〈http://www.emeraldinsight.com/10.1108/07378830310467436>

[21]. Nikolaidou, Mara, Anagnostopoulos, Dimosthenis and Hatzopoulos, Michael. Development of Medical Digital Library Managing Multiple Collections.The Electronic Library. $23 \quad$ (2); $\quad 2005$, Apr. $221-236$. <http://www.emeraldinsight.com/10.1108/02640470510592933>

[22]. Nisonger, Thomas E.. A Review of the 1997 Collection Development and Management Literature.Collection Building. 18 (2); 1999 , June; $67-80$

[23]. Olaojo P.O., \& Akewukeke, R.A. (2006). Collection development policies: Ground rules for planning university libraries. Library Philosophy and Practice 9 (1).

[24]. Rowley, Gordon and Black, William K. Consequences of Change: The Evolution of Collection Development. Collection Building. 15 (2); 1996, Jun.; 22-30. <http://www.emeraldinsight.com/10.1108/01604959610113879>

[25]. Seth, Mk, Ramesh, Db and Sahu, Jr. Utility of Library Collection in a Special Library: A Case Study.IASLIC Bulletin. 42 (3); 1997; 107-110.

[26]. Sinha, Reeta and Tucker, Cory. New Program Growth and Its Impact on Collection Assessment At UNLV Libraries.Library Hi Tech. 23 (3); 2005, Sep., 362-371. <http://www.emeraldinsight.com/10.1108/07378830510621775>

[27]. Susana, Barbara, Vignau, Sanchez and Meneses, Grizly. Collection Development Policies in University Libraries: A Space for Reflection.Collection Building. 24 (1); 2005, March; 35-43. <http://www.emeraldinsight.com/10.1108/01604950510576119>

[28]. Taylor, Donald. Standards Collection Development in an Academic Library.Collection Building. 18 (4); 1999, Dec., 148-152. <http://www.emeraldinsight.com/10.1108/01604959910303280>

[29]. Tucker, J.C. and Torrence, M. (2004) "Collection Development for New Libraries: Advice from the Trenches", Library Collections, Acquisition and Technical Services, 28(4), 339-349.

[30]. Vignau. Barbara Susana Sanchez (2005), "Collection Development Policies in University Libraries: A Space for Reflection", Collection Building, 24(1), 35-43.

[31]. Wessels, R. H. A. Optimizing the Size of Journal Collections in Libraries.Interlending \& Document Supply. 23 (3); 1995, Sep., 1921. <http://www.emeraldinsight.com/10.1108/02641619510155031>

[32]. Wittenbach, Stefanie (2005), "Restructuring Collection Development for Empowerment and Accountability", Collection Building, 24(3), 83-86. 